\title{
Factors predictive of invasive ductal carcinoma in cases preoperatively diagnosed as ductal carcinoma in situ
}

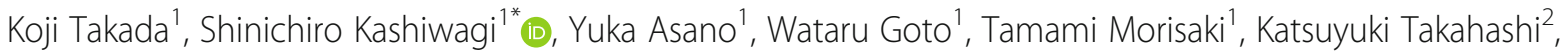
Hisakazu Fujita ${ }^{3}$, Tsutomu Takashima', Shuhei Tomita², Kosei Hirakawa ${ }^{1,4}$ and Masaichi Ohira 1,4

\begin{abstract}
Background: Invasion is often found during postoperative pathological examination of cases diagnosed as ductal carcinoma in situ (DCIS) by histological examinations such as core needle biopsy (CNB) or vacuum-assisted biopsy (VAB). A meta-analysis reported that $25.9 \%$ of invasive ductal carcinoma (IDC) cases are preoperatively diagnosed by CNB as DCIS. Risk factors for invasion have been studied by postoperative examination, but no factors have been found that could be obtained preoperatively from blood tests. In this study, we investigated factors predictive of invasion based on preoperative blood tests in patients diagnosed with DCIS by preoperative biopsy.
\end{abstract}

Methods: In this study, 118 patients who were diagnosed with DCIS by preoperative biopsy were included. Biopsies were performed with 16-gauge CNB or VAB. Peripheral blood was obtained at the time of diagnosis. This study evaluated absolute platelet count, absolute lymphocyte count, lactate dehydrogenase, carcinoembryonic antigen, and cancer antigen 15-3 (CA15-3). The platelet-lymphocyte ratio (PLR) was calculated by dividing the absolute platelet count by the absolute lymphocyte count, and patients were grouped into high PLR $(\geq 160.0)$ and low PLR (<160.0) groups.

Results: Invasion was found more frequently after surgery in pathologically high-grade cases than in pathologically not-high-grade cases $(p=0.015)$. The median PLR was 138.9 and 48 patients $(40.7 \%)$ were classified into the high PLR group. The high PLR group was significantly more likely to have invasion detected by the postoperative pathology than the low PLR group $(p=0.018)$. In multivariate analysis of factors predictive of invasion in postoperative pathology, a high PLR $(p=0.006$, odds ratio $[O R]=3.526)$ and biopsy method (VAB vs. CNB, $p=0.001$, $\mathrm{OR}=0.201)$ was an independent risk factor.

Conclusions: The PLR may be a predictor of invasion in the postoperative pathology for patients diagnosed with DCIS by preoperative biopsy.

Keywords: Invasive ductal carcinoma, Ductal carcinoma in situ, Invasion, Platelet-lymphocyte ratio, Biopsy, Surgery

\footnotetext{
* Correspondence: spqv9ke9@view.ocn.ne.jp

'Department of Breast and Endocrine Surgery, Osaka City University

Graduate School of Medicine, 1-4-3 Asahi-machi, Abeno-ku, Osaka 545-8585,

Japan

Full list of author information is available at the end of the article
}

(c) The Author(s). 2020 Open Access This article is licensed under a Creative Commons Attribution 4.0 International License, which permits use, sharing, adaptation, distribution and reproduction in any medium or format, as long as you give appropriate credit to the original author(s) and the source, provide a link to the Creative Commons licence, and indicate if changes were made. The images or other third party material in this article are included in the article's Creative Commons licence, unless indicated otherwise in a credit line to the material. If material is not included in the article's Creative Commons licence and your intended use is not permitted by statutory regulation or exceeds the permitted use, you will need to obtain permission directly from the copyright holder. To view a copy of this licence, visit http://creativecommons.org/licenses/by/4.0/ The Creative Commons Public Domain Dedication waiver (http://creativecommons.org/publicdomain/zero/1.0/) applies to the data made available in this article, unless otherwise stated in a credit line to the data. 


\section{Background}

Ductal carcinoma in situ (DCIS) is not an invasive malignant tumor; hence, it does not have the ability to metastasize. Therefore, the necessity of surgical treatment and sentinel lymph node biopsy for DCIS has been studied [1-4]. However, DCIS is diagnosed by histological examinations such as core needle biopsy (CNB) or vacuum-assisted biopsy (VAB), and invasion is often found in the postoperative pathological examination. A meta-analysis reported $25.9 \%(18.6-37.2 \%)$ of invasive ductal carcinomas (IDCs) are preoperatively diagnosed as DCIS by CNB [5]. Although risk factors have been examined, no such factors exist that can be identified easily using blood tests.

Cancer affects the general body condition as it progresses. In particular, changes in the blood composition are often observed starting from an early stage. Tumor markers are often correlated with progression and they have been reported to change following recurrence before other symptoms can be detected using different tests [6-8]. Carcinoembryonic antigen (CEA) and cancer antigen 15-3 (CA15-3) are commonly used as tumor markers for breast cancer. The white blood cell population and blood chemistry can also change. Lactate dehydrogenase $(\mathrm{LDH})$ is one of the most important metabolic enzymes involved in glycolysis [9]. An increase in serum LDH is observed with tissue destruction caused by cancerous growth [10], and serum LDH values have been reported to be consistent with clinical TNM staging $[10,11]$. Furthermore, the peripheral blood platelet-lymphocyte ratio (PLR) has been reported to be useful for predicting prognosis [12-14], and results from a meta-analysis suggested a correlation between the PLR and progression in breast cancer [12].

Therefore, we hypothesized that there may be a difference in blood test results if invasion occurs in patients diagnosed with DCIS by preoperative biopsy. In this study, we identified predictors of invasion from preoperative blood tests in patients diagnosed with DCIS by preoperative biopsy.

\section{Methods}

\section{Patients}

In this study, 100 and 18 patients who were diagnosed with DCIS by preoperative biopsy from August 2007 to January 2018 at the Osaka City University Hospital were included. Two breast pathologists jointly performed the pathological diagnosis and examination. The grade of DCIS was based on the World Health Organization classification [15]. The presence of comedonecrosis and intraductal calcification was examined and lymphoid infiltrate was evaluated with reference to previous reports $[16,17]$. Patients with multiple breast cancers were excluded, as were patients with a history of cancer regardless of breast cancer. Biopsies were performed by 16-gauge $\mathrm{CNB}$ or VAB with ultrasonography at the discretion of the attending physician. All patients underwent mastectomy or breast-conserving surgery. In both preoperative biopsy and postoperative pathological examination, invasion was examined by HematoxylinEosin staining and immunohistochemical staining. Furthermore, the expression of the estrogen receptor (ER), progesterone receptor (PgR), human epidermal growth factor receptor 2 (HER2), and Ki67 was evaluated by immunohistochemical staining in the biopsy tissue. All patients underwent ultrasonography and computed tomography, and 90 patients (76.3\%) underwent magnetic resonance imaging. Based on these results, tumor size was measured. None of the patients in this study had a suspected invasive carcinoma detected by imaging. Cases that were suspected of having lymph node metastases in the image were diagnosed as IDC even if they were diagnosed with DCIS by biopsy, and were excluded from this study.

\section{Blood sample analysis}

Peripheral blood was obtained before the biopsy. This study evaluated absolute platelet count, absolute lymphocyte count, LDH, CEA, and CA15-3. Patients in whom any of these variables was not measured were excluded from the study. The number of blood cells was determined using a hemocytometer. Percentages of different cell types were determined using a Coulter LH 750 Hematology Analyzer (Beckman Coulter, Brea, CA, USA). The PLR was calculated from the preoperative blood sample by dividing the absolute platelet count by the absolute lymphocyte count. Based on previous studies, a PLR value of 160.0 was used as the cutoff value to discriminate between a high PLR $(\geq 160.0)$ and a low PLR (<160.0) [18]. For LDH, CEA, and CA15-3, each upper limit of normal range (ULN) was set as a cut-off value (LDH: $120-242 \mathrm{IU} / \mathrm{L}, \mathrm{CEA}: \leq 5.0 \mathrm{ng} / \mathrm{mL}, \mathrm{CA} 15-3$ : $\leq 25.0 \mathrm{U} / \mathrm{mL}$ ).

\section{Statistical analysis}

All statistical analysis was performed with the JMP software package (SAS, Tokyo, Japan). The relationship between each factor was examined using Pearson's chisquare test. The odds ratio (OR) and 95\% confidence interval (CI) were calculated by logistic analysis. Multivariable analysis was performed using the multivariable logistic regression model. Significance was defined as a $p$ value of less than 0.05 .

\section{Results}

\section{Clinicopathological features}

The clinicopathological features of 118 patients who were diagnosed with DCIS by preoperative biopsy and 
met the conditions of this study are shown in Table 1 . The median age was 51 (range, 30-78) years, and the median tumor diameter was $17.7 \mathrm{~mm}$ (range, 3.0-50.0 $\mathrm{mm})$. A breast lump was the most common cause of consultation in 63 patients (53.4\%). As for other symptoms for consultation, 13 patients $(11.0 \%)$ had nipple

Table 1 Clinicopathological features of 118 cases diagnosed with DCIS by preoperative biopsy

\begin{tabular}{|c|c|}
\hline Parameters & Number of patients $(n=118)(\%)$ \\
\hline Age at operation (years old) & $51(30-78)$ \\
\hline \multicolumn{2}{|l|}{ Symptoms } \\
\hline Asymptomatic / Symptomatic & 42 (35.6\%) / 76 (64.4\%) \\
\hline \multicolumn{2}{|l|}{ Palpability } \\
\hline Impalpabe / Palpable & $33(28.0 \%)$ / 85 (72.0\%) \\
\hline Tumor size (mm) & $17.7(3.0-50.0)$ \\
\hline \multicolumn{2}{|l|}{ Biopsy device } \\
\hline $\begin{array}{l}\text { Core needle biopsy / } \\
\text { Vacuum-assisted biopsy }\end{array}$ & $67(56.8 \%) / 51(43.2 \%)$ \\
\hline \multicolumn{2}{|l|}{ Estrogen receptor } \\
\hline Negative / Positive & $22(18.6 \%) / 96(81.4 \%)$ \\
\hline \multicolumn{2}{|l|}{ Progesterone receptor } \\
\hline Negative / Positive & $37(31.4 \%) / 81(68.6 \%)$ \\
\hline \multicolumn{2}{|l|}{ HER2 } \\
\hline$\leq 2 / 3$ & 101 (85.6\%) / 17 (14.4\%) \\
\hline \multicolumn{2}{|l|}{ Ki67 } \\
\hline$\leq 14 \% />14 \%$ & $98(83.1 \%) / 20$ (16.9\%) \\
\hline \multicolumn{2}{|l|}{ Grade of DCIS } \\
\hline Low, intermediate / High & $98(83.1 \%) / 20$ (16.9\%) \\
\hline \multicolumn{2}{|l|}{ Comedonecrosis } \\
\hline Absence / Presence & $54(45.8 \%) / 64$ (54.2\%) \\
\hline \multicolumn{2}{|l|}{ Intraductal calcification } \\
\hline Absence / Presence & 99 (83.9\%) / 19 (16.1\%) \\
\hline \multicolumn{2}{|l|}{ Lymphoid infiltrate } \\
\hline $\begin{array}{l}\text { Negative, mild / moderate, } \\
\text { severe }\end{array}$ & 83 (70.3\%) / 35 (29.7\%) \\
\hline \multicolumn{2}{|l|}{ Postoperative pathology } \\
\hline $\begin{array}{l}\text { DCIS only / Invasive ductal } \\
\text { carcinoma }\end{array}$ & 70 (59.3\%) / 48 (40.7\%) \\
\hline Platelets-lymphocyte ratio & median 138.9 (range, 55.0-292.0) \\
\hline Low / High & 70 (59.3\%) / 48 (40.7\%) \\
\hline LDH & median 170 (range, 121-452) \\
\hline$\leq \cup L N />U L N$ & 105 (89.0\%) / 13 (11.0\%) \\
\hline CEA & median 1.6 (range, <0.5-12.4) \\
\hline$\leq \cup L N />U L N$ & $111(94.1 \%) / 7$ (5.9\%) \\
\hline CA15-3 & median 6.6 (range, $<0.5-40.8$ ) \\
\hline$\leq \cup L N />U L N$ & $115(97.5 \%) / 3(2.5 \%)$ \\
\hline
\end{tabular}

DCIS Ductal carcinoma in situ, HER2 Human epidermal growth factor receptor 2, LDH Lactate dehydrogenease, CEA Carcinoembryonic antigen, ULN Upper limit of normal discharge, one patient $(0.8 \%)$ had skin tangles, and one patient $(0.8 \%)$ had discomfort. Six patients with breast lumps and three patients (2.5\%) with nipple discharge had pain. Of all patients, 76 (64.4\%) were detected as having subjective symptoms, while 42 (35.6\%) were asymptomatic. Forty patients $(33.9 \%)$ were found by breast cancer screening, and two patients $(1.7 \%)$ were found by CT examination for other diseases. At consultation, a tumor was palpable in 85 patients $(72.0 \%)$. VAB was selected for 51 patients (43.2\%), but 67 patients (56.8\%), which is more than half, were diagnosed preoperatively by 16 -Gauge CNB. Ninety-six patients (81.4\%) had ER-positive tumors, and 81 patients $(68.6 \%)$ had PgR-positive tumors. Seventeen patients (14.4\%) had a score of $3+$ for HER2. Ki67 expression was detected in $>14 \%$ in 20 patients $(16.9 \%)$. Twenty preoperative biopsy specimens $(16.9 \%)$ were pathologically high-grade. The eight patients diagnosed with low grade by biopsy had the diagnosis changed to intermediate grade by postoperative pathological examination, and two patients diagnosed with intermediate grade by biopsy had the diagnosis changed to low grade by postoperative pathological examination. However, in no patient, diagnosis was changed from low or intermediate to high grade or from high to not-high grade by postoperative pathological examination. Comedonecrosis was found in 64 patients (54.2\%), and intraductal calcification was found in 19 cases (16.1\%). As for lymphoid infiltrate, 35 patients (29.7\%) were evaluated as moderate or severe. Forty-eight patients $(40.7 \%)$ were found to have invasion by postoperative pathological examination.

The median LDH level was 170 IU/L (range, 121-452 $\mathrm{IU} / \mathrm{L}$ ), and it was higher than the ULN in 13 patients (11.0\%). The median CEA level was $1.6 \mathrm{ng} / \mathrm{mL}$ (range, < $0.5-12.4 \mathrm{ng} / \mathrm{mL}$ ), and it was higher than the ULN in 7 patients (5.9\%). In addition, the median CA15-3 level was $6.6 \mathrm{U} / \mathrm{mL}$ (range, $<0.5-40.8 \mathrm{U} / \mathrm{mL}$ ), and in 3 patients $(2.5 \%)$ it was higher than the ULN. The median PLR was 138.9 (range, 55.0-292.0), and 48 patients (40.7\%) who had a PLR > 160 were assigned to the high PLR group.

\section{Correlations between clinicopathological features and postoperative pathology}

The correlations between clinicopathological features and postoperative pathology are listed in Table 2. DCIS detected by symptom was significantly more invasive than asymptomatic DCIS $(p=0.047)$. In cases in which the tumor was palpable before surgery, the postoperative pathology tended to be IDC $(p=0.065)$. In cases in which the tumor diameter was larger than $20 \mathrm{~mm}$, the probability of the postoperative pathology being IDC was significantly higher $(p=0.024)$. Cases biopsied by $\mathrm{VAB}$ were significantly more likely to be diagnosed as 
Table 2 Correlation between postoperative pathology and clinicopathological features

\begin{tabular}{|c|c|c|}
\hline Parameters & Postoperati & athology \\
\hline & $\begin{array}{l}\text { DCIS only } \\
(n=70)\end{array}$ & $\begin{array}{l}\text { Invasive ductal } \\
\text { carcinoma } \\
(n=48)\end{array}$ \\
\hline
\end{tabular}

Age at operation (years old)

$\leq 60 \quad 50(71.4 \%) \quad 33(68.8 \%)$

$>60 \quad 20(28.6 \%) \quad 15(31.3 \%)$

Symptoms

Asymptomatic
Symptomatic
Palpability
Impalpabe
Palpable

Tumor size $(\mathrm{mm}$
$\leq 20.0$
$>20.0$

Biopsy device

$\begin{array}{lll}\begin{array}{l}\text { Core needle biopsy } \\ \begin{array}{l}\text { Vacuum-assisted } \\ \text { biopsy }\end{array}\end{array} & 32(45.7 \%) & 35(72.9 \%) \\ \begin{array}{l}\text { Estrogen receptor } \\ \text { Negative }\end{array} & 9(27.1 \%) \\ \text { Positive } & 91(87.1 \%) & 35(72.9 \%)\end{array}$

Progesterone receptor

$\begin{array}{ccc}\begin{array}{l}\text { Negative } \\ \text { Positive } \\ \text { HER2 }\end{array} & 18(25.7 \%) & 19(39.6 \%) \\ \leq 2 & 52(74.3 \%) & 29(60.4 \%) \\ 3 & & \\ \text { Ki67 } & 63(90.0 \%) & 38(79.2 \%) \\ \leq 14 \% & 7(10.0 \%) & 10(20.8 \%) \\ >14 \% & & \\ & 60(85.7 \%) & 38(79.2 \%) \\ & 10(14.3 \%) & 10(20.8 \%)\end{array}$

Grade of DCIS

Low, intermediate
High
Comedonecrosis
Absence

Presence

Intraductal calcification

$\begin{array}{lll}\text { Absence } & 62(88.6 \%) & 37(77.1 \%) \\ \text { Presence } & 8(11.4 \%) & 11(22.9 \%) \\ \text { Lymphoid infiltrate } & & \\ \text { Negative, mild } & 56(80.0 \%) & 27(56.3 \%) \\ \text { Moderate, severe } & 14(20.0 \%) & 21(43.8 \%)\end{array}$

Platelets-lymphocyte ratio
Table 2 Correlation between postoperative pathology and clinicopathological features (Continued)

\begin{tabular}{llll}
\hline Parameters & \multicolumn{2}{l}{ Postoperative pathology } & $p$ value \\
\cline { 2 - 3 } & $\begin{array}{l}\text { DCIS only } \\
(n=70)\end{array}$ & $\begin{array}{l}\text { Invasive ductal } \\
\text { carcinoma } \\
(n=48)\end{array}$ & \\
\hline Low & $50(71.4 \%)$ & $24(50.0 \%)$ & \\
High & $20(28.6 \%)$ & $24(50.0 \%)$ & 0.018 \\
LDH & $63(90.0 \%)$ & $42(87.5 \%)$ & \\
$\leq$ ULN & $7(10.0 \%)$ & $6(12.5 \%)$ & 0.670 \\
$>$ ULN & & & \\
CEA & $66(94.3 \%)$ & $45(93.8 \%)$ & 0.904 \\
$\leq$ ULN & $4(5.7 \%)$ & $4(5.7 \%)$ & \\
$>$ ULN & & & \\
CA15-3 & $69(98.6 \%)$ & $46(95.8 \%)$ & \\
$\leq$ ULN & $1(1.4 \%)$ & $2(4.2 \%)$ & \\
$>$ ULN & &
\end{tabular}

0.003 DCIS by postoperative pathology than those biopsied by CNB $(p=0.003)$. Although no significant difference was observed based on immunohistochemical staining, invasion was found more frequently after surgery in pathologically high-grade cases than in pathologically nothigh-grade cases $(p=0.015)$. Patients with comedonecrosis and those with intraductal calcification tended to have more invasive disease by postoperative pathology than patients without those conditions $(p=0.061, p=$ 0.098 , respectively). Invasion rate was significantly higher in patients evaluated as moderate or severe for lymphoid infiltrate than in those evaluated as negative or mild $(p=0.018)$ (Fig. 1).

Examination of preoperative blood sampling results showed no significant difference in LDH level or tumor markers based on pre- and postoperative concordance. However, the high PLR group was significantly more likely to show invasion in postoperative pathology than the low PLR group $(p=0.018)$. The correlations between the PLR and other clinical factors were examined, but there was no clear correlation (Table 3). In the univariate analysis of factors predictive of invasion in postoperative pathology, a high PLR $(p=0.018, \mathrm{OR}=2.500)$ was a factor, as were larger tumor size $(p=0.024, \mathrm{OR}=2.372)$, high grade of DCIS ( $p=0.015, \mathrm{OR}=3.343)$, moderate or severe for lymphoid infiltrate $(p=0.006, \mathrm{OR}=3.111)$, and biopsy method (VAB vs. CNB, $p=0.003$, OR = 0.313) (Fig. 1). Moreover, in multivariate analysis of factors predictive of invasion in postoperative pathology, a high PLR $(p=0.006, \mathrm{OR}=3.526)$ and biopsy method (VAB vs. $\mathrm{CNB}, p=0.001$, $\mathrm{OR}=0.201$ ) were independent factors (Table 4). 


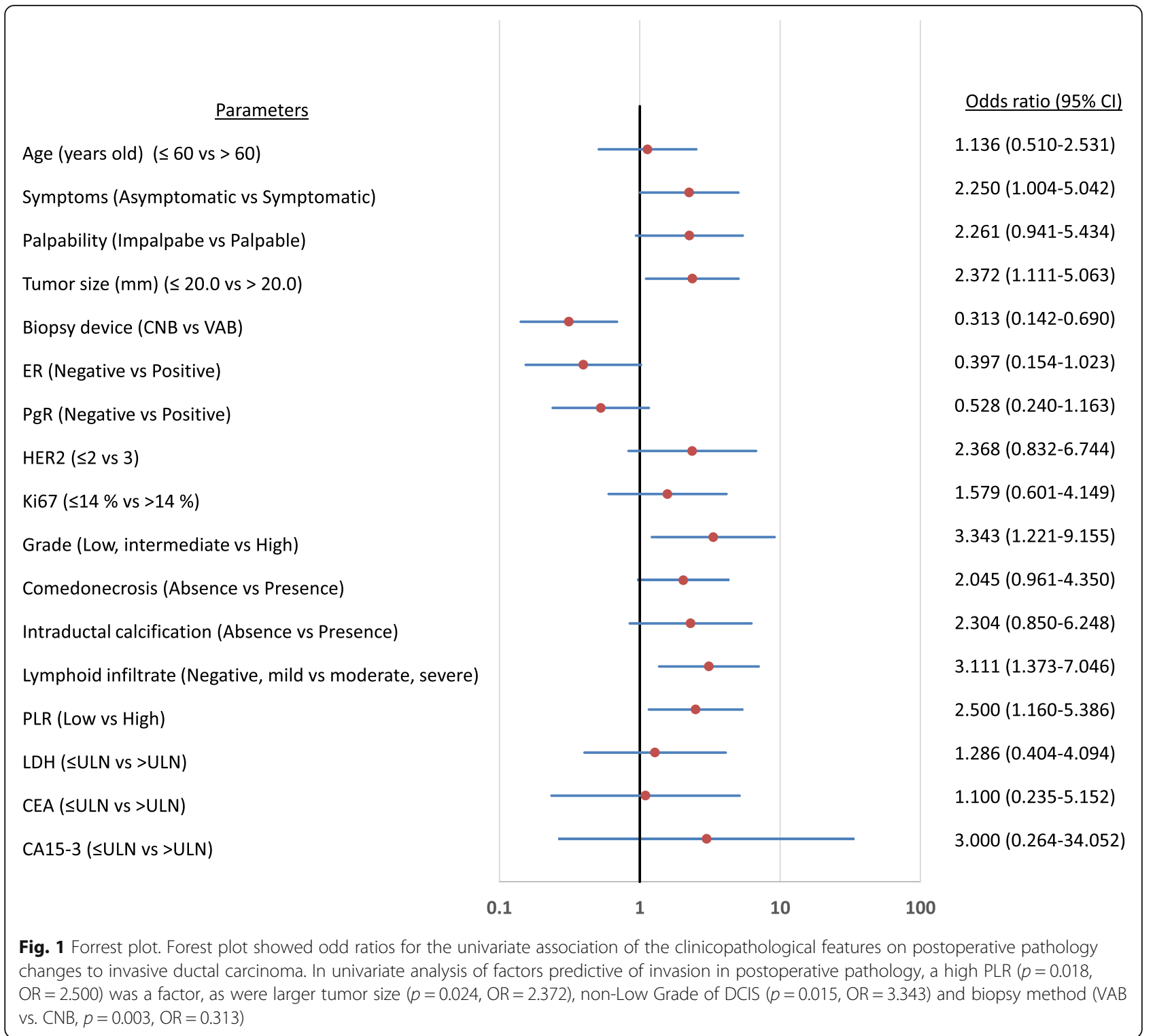

\section{Discussion}

IDC may be misdiagnosed as DCIS by preoperative biopsy. As mentioned above, 25.9\% (18.6-37.2\%) of cases preoperatively diagnosed as DCIS have been reported to be IDC according to a meta-analysis [5]. However, the ratio of misdiagnosis in this study was $40.7 \%$, higher than that previously reported. This was greatly influenced by the biopsy method. The metaanalysis found that one of the risk factors for underestimation of invasion was sampling by 14-Gauge CNB instead of 11-Gauge CNB. In contrast, for more than half of the cases in our study 16-Gauge CNB was used for biopsy. Therefore, in patients diagnosed with DCIS by VAB, the rate of postoperative invasion detection was $27.1 \%$, in contrast with that found in patients diagnosed by CNB, which was $52.2 \%$.
Certainly, the use of VAB causes stronger pain and has higher medical costs than CNB. However, in the future, $\mathrm{CNB}$ with a thicker puncture needle or VAB is considered necessary for a more accurate preoperative diagnosis.

In addition to the different rate of postoperative invasion detected in our study, clinicopathological features also differed from those shown in the metaanalysis [5]. According to the meta-analysis, only $8.3 \%$ of all cases diagnosed with DCIS by preoperative biopsy were palpable, and $98.3 \%$ were detected by breast cancer screening. While, the pathological diagnosis of high grade was $49.4 \%$, accounting for about half of the cases, in this study, $64.4 \%$ of patients had symptoms and $72.0 \%$ were palpable. The pathological diagnosis of high grade was $16.9 \%$, which was low. 
Table 3 Correlation between platelets-lymphocyte ratio and clinicopathological features

\begin{tabular}{|c|c|c|c|}
\hline \multirow[t]{2}{*}{ Parameters } & \multicolumn{2}{|c|}{ Platelets-lymphocyte ratio } & \multirow[t]{2}{*}{$p$ value } \\
\hline & $\begin{array}{l}\text { Low } \\
(n=74)\end{array}$ & $\begin{array}{l}\text { High } \\
(n=44)\end{array}$ & \\
\hline \multicolumn{4}{|l|}{ Age at operation (years old) } \\
\hline$\leq 60$ & $51(68.9 \%)$ & $32(72.7 \%)$ & \\
\hline$>60$ & $23(31.1 \%)$ & $12(27.3 \%)$ & 0.661 \\
\hline \multicolumn{4}{|l|}{ Symptoms } \\
\hline Asymptomatic & $29(39.2 \%)$ & $13(29.5 \%)$ & \\
\hline Symptomatic & $45(60.8 \%)$ & $31(70.5 \%)$ & 0.290 \\
\hline \multicolumn{4}{|l|}{ Palpability } \\
\hline Impalpabe & $22(29.7 \%)$ & $11(25.0 \%)$ & \\
\hline Palpable & $52(70.3 \%)$ & $33(75.0 \%)$ & 0.580 \\
\hline \multicolumn{4}{|l|}{ Tumor size $(\mathrm{mm})$} \\
\hline$\leq 20.0$ & $45(60.8 \%)$ & $26(59.1 \%)$ & \\
\hline$>20.0$ & $29(39.2 \%)$ & $18(40.9 \%)$ & 0.854 \\
\hline \multicolumn{4}{|l|}{ Biopsy device } \\
\hline Core needle biopsy & $42(56.8 \%)$ & $25(56.8 \%)$ & \\
\hline Vacuum-assisted biopsy & $32(43.2 \%)$ & 19 (43.2\%) & 0.995 \\
\hline \multicolumn{4}{|l|}{ Estrogen receptor } \\
\hline Negative & $15(20.3 \%)$ & 7 (15.9\%) & \\
\hline Positive & $59(79.7 \%)$ & $37(84.1 \%)$ & 0.556 \\
\hline \multicolumn{4}{|l|}{ Progesterone receptor } \\
\hline Negative & $25(33.8 \%)$ & $12(27.3 \%)$ & \\
\hline Positive & $49(66.2 \%)$ & $32(72.7 \%)$ & 0.461 \\
\hline \multicolumn{4}{|l|}{ HER2 } \\
\hline$\leq 2$ & $63(82.4 \%)$ & 40 (90.9\%) & \\
\hline 3 & $13(17.6 \%)$ & $4(9.1 \%)$ & 0.205 \\
\hline \multicolumn{4}{|l|}{ Ki67 } \\
\hline$\leq 14 \%$ & $62(83.8 \%)$ & $36(81.8 \%)$ & \\
\hline$>14 \%$ & $12(16.2 \%)$ & $8(18.2 \%)$ & 0.783 \\
\hline \multicolumn{4}{|l|}{ Grade of DCIS } \\
\hline Low, intermediate & $60(81.1 \%)$ & 38 (86.4\%) & \\
\hline High & $14(18.9 \%)$ & $6(13.6 \%)$ & 0.460 \\
\hline \multicolumn{4}{|l|}{ Comedonecrosis } \\
\hline Absence & $36(48.6 \%)$ & 18 (40.9\%) & \\
\hline Presence & $38(51.4 \%)$ & $26(59.1 \%)$ & 0.666 \\
\hline \multicolumn{4}{|l|}{ Intraductal calcification } \\
\hline Absence & $63(85.1 \%)$ & $36(81.8 \%)$ & \\
\hline Presence & $11(14.9 \%)$ & $8(18.2 \%)$ & 0.635 \\
\hline \multicolumn{4}{|l|}{ Lymphoid infiltrate } \\
\hline Negative, mild & $49(66.2 \%)$ & $34(77.3 \%)$ & \\
\hline Moderate, severe & $25(33.8 \%)$ & $10(22.7 \%)$ & 0.204 \\
\hline \multicolumn{4}{|l|}{$\mathrm{LDH}$} \\
\hline$\leq U L N$ & $67(90.5 \%)$ & 38 (86.4\%) & \\
\hline$>$ ULN & $7(9.5 \%)$ & $6(13.6 \%)$ & 0.484 \\
\hline
\end{tabular}

Table 3 Correlation between platelets-lymphocyte ratio and clinicopathological features (Continued)

\begin{tabular}{|c|c|c|c|}
\hline \multirow[t]{2}{*}{ Parameters } & \multicolumn{2}{|c|}{ Platelets-lymphocyte ratio } & \multirow[t]{2}{*}{$p$ value } \\
\hline & $\begin{array}{l}\text { Low } \\
(n=74)\end{array}$ & $\begin{array}{l}\text { High } \\
(n=44)\end{array}$ & \\
\hline \multicolumn{4}{|l|}{ CEA } \\
\hline$\leq \cup L N$ & 70 (94.6\%) & 41 (93.2\%) & \\
\hline$>$ ULN & $4(5.4 \%)$ & $3(6.8 \%)$ & 0.753 \\
\hline \multicolumn{4}{|l|}{ CA15-3 } \\
\hline$\leq \cup L N$ & 71 (95.9\%) & $44(100.0 \%)$ & \\
\hline$>$ ULN & $3(4.1 \%)$ & $0(0.0 \%)$ & 0.176 \\
\hline \multicolumn{4}{|l|}{ Postoperative pathology } \\
\hline DCIS only & $50(67.6 \%)$ & $20(45.5 \%)$ & \\
\hline Invasive ductal carcinoma & $24(32.4 \%)$ & $24(54.5 \%)$ & 0.018 \\
\hline
\end{tabular}

This may be due to the low screening rate in Japan. It is reported that the screening rate in Japan is about $40 \%$, lower than in other countries [19]. The number of DCIS detected early that could not be palpated was small; however, as they progressed, the proportion of patients with symptoms increased, and they became palpable. High grade DCIS may have been diagnosed as invasive ductal carcinoma at biopsy because it has already acquired invasiveness. The reason for a low ratio of a score of $3+$ for HER2 may be the same. Although the rate of HER2 overexpression in DCIS has been reported to be from 28 to $65 \%$ [20], the rate shown in this study was still lower. We considered that the low ratio of high grade DCIS caused this discrepancy because high grade DCIS was reported to be frequently negative for ER and overexpress HER2 [20].

Various factors other than biopsy devices are considered risk factors for underestimation of invasion; high grade, tumor size larger than $20 \mathrm{~mm}$, and palpability have been previously identified as risk factors [5]. One study also reported hormone receptor negativity as a risk factor [21]. There are reports suggesting that comedonecrosis, intraductal calcification, and lymphoid infiltrate are risk factors $[16,17]$. Although this study showed differences in the ratio of invasion by postoperative pathology and clinicopathological features from those presented in previous reports, similar results were found regarding risk factors. However, this study focused on preoperative blood test results, and invasion in postoperative pathology was found significantly more frequently in patients with a high PLR than in patients with a low PLR. Platelets and growth factors such as plateletderived growth factor and transforming growth factor- $\beta$ are known to promote tumor growth [22-26]. In 
Table 4 Univariate and multivariate analysis with upstaging preoperatively DCIS to invasive cancer

\begin{tabular}{|c|c|c|c|c|c|c|}
\hline \multirow[b]{2}{*}{ Parameters } & \multicolumn{3}{|c|}{ Univarite analysis } & \multicolumn{3}{|c|}{ Multivarite analysis } \\
\hline & Odd ratio & $95 \% \mathrm{Cl}$ & $p$ value & Odd ratio & $95 \% \mathrm{Cl}$ & $p$ value \\
\hline \multicolumn{7}{|l|}{ Age at operation (years old) } \\
\hline$\leq 60$ vs $>60$ & 1.136 & $0.510-2.531$ & 0.754 & & & \\
\hline \multicolumn{7}{|l|}{ Symptoms } \\
\hline Asymptomatic vs Symptomatic & 2.250 & $1.004-5.042$ & 0.047 & 2.226 & $0.638-8.463$ & 0.217 \\
\hline \multicolumn{7}{|l|}{ Palpability } \\
\hline Impalpabe vs Palpable & 2.261 & $0.941-5.434$ & 0.065 & 0.865 & $0.201-3.568$ & 0.842 \\
\hline \multicolumn{7}{|l|}{ Tumor size (mm) } \\
\hline$\leq 20.0$ vs $>20.0$ & 2.372 & $1.111-5.063$ & 0.024 & 2.647 & $0.908-8.261$ & 0.075 \\
\hline \multicolumn{7}{|l|}{ Biopsy device } \\
\hline CNB vs VAB & 0.313 & $0.142-0.690$ & 0.003 & 0.201 & $0.068-0.534$ & 0.001 \\
\hline \multicolumn{7}{|l|}{ Estrogen receptor } \\
\hline Negative vs Positive & 0.397 & $0.154-1.023$ & 0.051 & 1.008 & $0.227-4.633$ & 0.991 \\
\hline \multicolumn{7}{|l|}{ Progesterone receptor } \\
\hline Negative vs Positive & 0.528 & $0.240-1.163$ & 0.111 & & & \\
\hline \multicolumn{7}{|l|}{ HER2 } \\
\hline$\leq 2$ vs 3 & 2.368 & $0.832-6.744$ & 0.100 & 1.739 & $0.361-8.417$ & 0.484 \\
\hline \multicolumn{7}{|l|}{ Ki67 } \\
\hline$\leq 14 \%$ vs $>14 \%$ & 1.579 & $0.601-4.149$ & 0.352 & & & \\
\hline \multicolumn{7}{|l|}{ Grade of DCIS } \\
\hline Low, intermediate vs High & 3.343 & $1.221-9.155$ & 0.015 & 2.234 & $0.526-9.961$ & 0.274 \\
\hline \multicolumn{7}{|l|}{ Comedonecrosis } \\
\hline Absence vs Presence & 2.045 & $0.961-4.350$ & 0.061 & 0.817 & $0.303-2.133$ & 0.682 \\
\hline \multicolumn{7}{|l|}{ Intraductal calcification } \\
\hline Absence vs Presence & 2.304 & $0.850-6.248$ & 0.098 & 2.525 & $0.748-9.019$ & 0.136 \\
\hline \multicolumn{7}{|l|}{ Lymphoid infiltrate } \\
\hline Negative, mild / moderate, severe & 3.111 & $1.373-7.046$ & 0.006 & 2.296 & $0.752-7.215$ & 0.144 \\
\hline \multicolumn{7}{|l|}{ Platelets-lymphocyte ratio } \\
\hline Low vs High & 2.500 & $1.160-5.386$ & 0.018 & 3.526 & $1.423-9.258$ & 0.006 \\
\hline \multicolumn{7}{|l|}{ LDH } \\
\hline$\leq U L N$ vS $>$ ULN & 1.286 & $0.404-4.094$ & 0.670 & & & \\
\hline \multicolumn{7}{|l|}{ CEA } \\
\hline$\leq U L N$ vs $>$ ULN & 1.100 & $0.235-5.152$ & 0.904 & & & \\
\hline \multicolumn{7}{|l|}{ CA15-3 } \\
\hline$\leq U L N$ vs $>$ ULN & 3.000 & $0.264-34.052$ & 0.353 & & & \\
\hline
\end{tabular}

DCIS Ductal carcinoma in situ, CNB Core needle biopsy. VAB Vacuum-assisted biopsy. HER2 Human epidermal growth factor receptor 2, LDH Lactate dehydrogenease, ULN Upper limit of normal, CEA Carcinoembryonic antigen, $\mathrm{Cl}$ Confidence intervals

addition, immunity is involved in the progression of cancer, and lymphocytes play a key role in the host antitumor immune function [27]. This study was based on the hypothesis that blood test changes may occur as cancer progresses. LDH and tumor markers showed no significant difference based on pre- and postoperative concordance, but invasion was significantly more likely to be found in the high PLR group than in the low PLR group. Perhaps PLR did not rise because of the invasion, but in an environment with a high PLR, the tumor could easily acquire invasive ability. High proliferative potential and malignancy, such as HER2-positive and high nuclear grade, cause comedonecrosis and intraductal calcification. If invasion appears, the invasive cancer may have caused inflammation in the surrounding interstitium. In recent years, one study has reported changes in the 
immune microenvironment of tumors in DCIS and IDC. According to this report, immune escape is progressing in the invasion part [28]. In other words, the trigger of invasion requires a deterioration of the immune environment, and PLR may be the indicator for such deterioration. Although the actions of platelets and lymphocytes are generally reported, it is uncertain whether they actually affect DCIS. In future, we need to examine the biological effects of platelets and lymphocytes on DCIS by immunostaining, gene analysis, and protein quantification in vitro.

There are some limitations to this study. First, there were many cases, in which biopsy was performed with 16-Gauge CNB, so the rate of IDC detection after the surgery was higher than that shown in previous reports. Secondly, some clinicopathological features, such as the ratio of palpability or the grade of DCIS, also differed from those shown in previous reports. The usefulness of mammography scores, so-called the Breast Imaging Reporting and Data System (BIRADS), has also been reported as a predictor [5]. Third, in this study only 65 patients $(55.1 \%)$ had mammography performed. Finally, since liver diseases and inflammation easily affect the absolute platelet count and lymphocyte count, it is also a limitation that the comorbidities were not included in the study. However, randomized trials are currently underway to investigate the outcomes during follow-up for lowgrade DCIS [29, 30]. One strength of this study is that the PLR can be evaluated relatively easily in clinical practice, and changes in DCIS can be found by evaluating the PLR over time. Furthermore, the current trend is that sentinel lymph node biopsy is being omitted in the diagnosis of DCIS [31, 32]. Some studies reported that metastasis to the sentinel lymph node is unlikely to be found by sentinel lymph node biopsy during surgery for DCIS [31,33]. If the PLR is high, the invasion may be found by postoperative pathological examination. In addition, chemotherapy may be less effective among these patients. Therefore, we believe that sentinel lymph node biopsy may still be needed in patients with high PLR.

\section{Conclusions}

The PLR may be a predictor of invasion in postoperative pathology for patients diagnosed with DCIS by preoperative biopsy.

\section{Abbreviations}

CA15-3: Cancer antigen 15-3; CEA: Carcinoembryonic antigen;

Cl: Confidence interval; CNB: Core needle biopsy; DCIS: Ductal carcinoma in situ; ER: Estrogen receptor; HER2: Human epidermal growth factor receptor 2; IDC: Invasive ductal carcinoma; LDH: Lactate dehydrogenase; OR: Odds ratio; PgR: Progesterone receptor; PLR: Platelet-lymphocyte ratio; ULN: Upper limit of normal; VAB: Vacuum-assisted biopsy

\section{Acknowledgements}

We thank Sayaka Tanaka and Masahiko Ohsawa (Department of Diagnostic Pathology, Osaka City University Graduate School of Medicine) for helpful advice regarding pathological diagnosis. And, we thank Yayoi Matsukiyo and Tomomi Okawa (Department of Surgical Oncology, Osaka City University Graduate School of Medicine) for helpful advice regarding data management.

\section{Authors' contributions}

KTakad participated in the design of the study and drafted the manuscript. SK participated in the design of the study and manuscript editing. YA, WG, TM and TT helped with study data collection and manuscript preparation. HF, KTakah and ST helped with study data collection and participated in its design. $\mathrm{KH}$ and $\mathrm{MO}$ conceived the study, and participated in its design and coordination and helped to draft the manuscript. All authors have read and approved the final manuscript.

\section{Funding}

This study was supported in part by Grants-in Aid for Scientific Research (KAKENHI, Nos. 17 K10559 and 19 K18067) from the Ministry of Education, Science, Sports, Culture and Technology of Japan. The funding body was not involved in the design of this study and collection, analysis, and interruption of data and in writing the manuscript.

\section{Availability of data and materials}

The datasets used and/or analyzed during the current study are available from the corresponding author on reasonable request.

\section{Ethics approval and consent to participate}

Written informed consent was obtained from all subjects. This research conformed to the provisions of the Declaration of Helsinki in 2013. All patients were informed of the investigational nature of this study and provided their written, informed consent. The study protocol was approved by the Ethics Committee of Osaka City University (\#926).

\section{Consent for publication}

Not applicable.

\section{Competing interests}

The authors declare that they have no competing interests.

\section{Author details}

${ }^{1}$ Department of Breast and Endocrine Surgery, Osaka City University Graduate School of Medicine, 1-4-3 Asahi-machi, Abeno-ku, Osaka 545-8585, Japan. ${ }^{2}$ Department of Pharmacology, Osaka City University Graduate School of Medicine, 1-4-3 Asahi-machi, Abeno-ku, Osaka 545-8585, Japan.

${ }^{3}$ Department of Scientific and Linguistic Fundamentals of Nursing, Osaka City University Graduate School of Nursing, 1-5-17 Asahi-machi, Abeno-ku, Osaka 545-0051, Japan. ${ }^{4}$ Department of Gastrointestinal Surgery, Osaka City University Graduate School of Medicine, 1-4-3 Asahi-machi, Abeno-ku, Osaka 545-8585, Japan.

Received: 14 December 2019 Accepted: 25 May 2020

Published online: 03 June 2020

\section{References}

1. van Roozendaal LM, Goorts B, Klinkert M, Keymeulen K, De Vries B, Strobbe LJA, Wauters CAP, van Riet YE, Degreef E, Rutgers EJT, et al. Sentinel lymph node biopsy can be omitted in DCIS patients treated with breast conserving therapy. Breast Cancer Res Treat. 2016;156(3):517-25.

2. Prendeville S, Ryan C, Feeley L, O'Connell F, Browne TJ, O'Sullivan MJ, Bennett MW. Sentinel lymph node biopsy is not warranted following a core needle biopsy diagnosis of ductal carcinoma in situ (DCIS) of the breast. Breast. 2015;24(3):197-200

3. Rosen PP, Braun DW Jr, Kinne DE. The clinical significance of pre-invasive breast carcinoma. Cancer. 1980;46(4 Suppl):919-25

4. Sagara Y, Mallory MA, Wong S, Aydogan F, DeSantis S, Barry WT, Golshan M. Survival benefit of breast surgery for low-grade ductal carcinoma in situ: a population-based cohort study. JAMA Surg. 2015;150(8):739-45.

5. Brennan ME, Turner RM, Ciatto S, Marinovich ML, French JR, Macaskill P, Houssami N. Ductal carcinoma in situ at core-needle biopsy: meta-analysis 
of underestimation and predictors of invasive breast cancer. Radiology. 2011;260(1):119-28.

6. Fu Y, Li H. Assessing clinical significance of serum CA15-3 and Carcinoembryonic antigen (CEA) levels in breast Cancer patients: a metaanalysis. Med Sci Monit. 2016;22:3154-62.

7. Harris L, Fritsche H, Mennel R, Norton L, Ravdin P, Taube S, Somerfield MR, Hayes DF, Bast RC Jr. American society of clinical o: American society of clinical oncology 2007 update of recommendations for the use of tumor markers in breast cancer. J Clin Oncol. 2007;25(33):5287-312.

8. Di Gioia D, Stieber P, Schmidt GP, Nagel D, Heinemann V, Baur-Melnyk A. Early detection of metastatic disease in asymptomatic breast cancer patients with whole-body imaging and defined tumour marker increase. $\mathrm{Br}$ J Cancer. 2015;112(5):809-18.

9. Gallo M, Sapio L, Spina A, Naviglio D, Calogero A, Naviglio S. Lactic dehydrogenase and cancer: an overview. Front Biosci (Landmark Ed). 2015; 20:1234-49.

10. Liu D, Wang D, Wu C, Zhang L, Mei Q, Hu G, Long G, Sun W. Prognostic significance of serum lactate dehydrogenase in patients with breast cancer: a meta-analysis. Cancer Manag Res. 2019;11:3611-9.

11. Agrawal A, Gandhe MB, Gupta D, Reddy MV. Preliminary study on serum lactate dehydrogenase (LDH)-prognostic biomarker in carcinoma breast. J Clin Diagn Res. 2016;10(3):BC06-8.

12. Zhang M, Huang XZ, Song YX, Gao P, Sun JX, Wang ZN. High platelet-tolymphocyte ratio predicts poor prognosis and Clinicopathological characteristics in patients with breast Cancer: a meta-analysis. Biomed Res Int. 2017;2017:9503025.

13. Zhu Y, Si W, Sun Q, Qin B, Zhao W, Yang J. Platelet-lymphocyte ratio acts as an indicator of poor prognosis in patients with breast cancer. Oncotarget. 2017:8(1):1023-30.

14. Asano Y, Kashiwagi S, Onoda N, Noda S, Kawajiri H, Takashima T, Ohsawa M, Kitagawa S, Hirakawa K. Platelet-lymphocyte ratio as a useful predictor of the therapeutic effect of Neoadjuvant chemotherapy in breast Cancer. PLoS One. 2016;11(7):e0153459.

15. Allred DC, Mohsin SK, Fuqua SA. Histological and biological evolution of human premalignant breast disease. Endocr Relat Cancer. 2001;8(1):47-61.

16. Hoorntje LE, Schipper ME, Peeters PH, Bellot F, Storm RK, Borel Rinkes IH. The finding of invasive cancer after a preoperative diagnosis of ductal carcinoma-in-situ: causes of ductal carcinoma-in-situ underestimates with stereotactic 14-gauge needle biopsy. Ann Surg Oncol. 2003;10(7):748-53.

17. Go EM, Chan SK, Vong JS, Lui PC, Chan AW, Ma TK, Ang MA, Law BK, Tan $\mathrm{PH}$, Tse GM. Predictors of invasion in needle core biopsies of the breast with ductal carcinoma in situ. Mod Pathol. 2010;23(5):737-42.

18. Cihan YB, Arslan A, Cetindag MF, Mutlu H. Lack of prognostic value of blood parameters in patients receiving adjuvant radiotherapy for breast cancer. Asian Pac J Cancer Prev. 2014;15(10):4225-31.

19. Uchida K, Ohashi H, Kinoshita S, Nogi H, Kato K, Toriumi Y, Yamashita A, Kamio M, Mimoto R, Takeyama H. Breast cancer screening and the changing population pyramid of Japan. Breast Cancer. 2015;22(2):172-6.

20. Siziopikou KP, Anderson SJ, Cobleigh MA, Julian TB, Arthur DW, Zheng P, Mamounas EP, Pajon ER, Behrens RJ, Eakle JF, Leasure NC, Atkins JN, Polikoff $J$ A, Seay TE, McCaskill-Stevens WJ, Rabinovitch R, Costantino JP, Wolmark N. Preliminary results of centralized HER2 testing in ductal carcinoma in situ (DCIS): NSABP B-43. Breast Cancer Res Treat. 2013;142(2):415-21.

21. Ozkan-Gurdal S, Cabioglu N, Ozcinar B, Muslumanoglu M, Ozmen V, Kecer $M$, Yavuz $E$, Igci A. Factors predicting microinvasion in ductal carcinoma in situ. Asian Pac J Cancer Prev. 2014;15(1):55-60.

22. Betsholtz C, Johnsson A, Heldin CH, Westermark B, Lind P, Urdea MS, Eddy R, Shows TB, Philpott K, Mellor AL, et al. cDNA sequence and chromosomal localization of human platelet-derived growth factor A-chain and its expression in tumour cell lines. Nature. 1986;320(6064):695-9.

23. Ross R, Masuda J, Raines EW, Gown AM, Katsuda S, Sasahara M, Malden LT, Masuko H, Sato H. Localization of PDGF-B protein in macrophages in all phases of atherogenesis. Science. 1990;248(4958):1009-12.

24. Heldin $\mathrm{CH}$, Westermark B. Growth factors: mechanism of action and relation to oncogenes. Cell. 1984;37(1):9-20.

25. Miyazono K, Yuki K, Takaku F, Wernstedt C, Kanzaki T, Olofsson A, Hellman U, Heldin CH. Latent forms of TGF-beta: structure and biology. Ann N Y Acad Sci. 1990;593:51-8.

26. Sporn MB, Roberts AB. Transforming growth factor-beta. Multiple actions and potential clinical applications. JAMA. 1989;262(7):938-41.
27. Lin EY, Pollard JW. Role of infiltrated leucocytes in tumour growth and spread. Br J Cancer. 2004;90(11):2053-8.

28. Gil Del Alcazar CR, Huh SJ, Ekram MB, Trinh A, Liu LL, Beca F, Zi X, Kwak M, Bergholtz H, Su Y, et al. Immune escape in breast Cancer during in situ to invasive carcinoma transition. Cancer Discov. 2017;7(10):1098-115.

29. Soumian S, Verghese ET, Booth M, Sharma N, Chaudhri S, Bradley S, Umranikar S, Millican-Slater RA, Hanby AM, Francis A. Concordance between vacuum assisted biopsy and postoperative histology: implications for the proposed low risk DCIS trial (LORIS). Eur J Surg Oncol. 2013;39(12):1337-40

30. Elshof LE, Tryfonidis K, Slaets L, van Leeuwen-Stok AE, Skinner VP, Dif N, Pijnappel RM, Bijker N, Rutgers EJ, Wesseling J. Feasibility of a prospective, randomised, open-label, international multicentre, phase III, non-inferiority trial to assess the safety of active surveillance for low risk ductal carcinoma in situ - the LORD study. Eur J Cancer. 2015;51(12):1497-510.

31. van Roozendaal LM, Goorts B, Klinkert M, Keymeulen KBMl, De Vries B, Strobbe LA, Wauters CAP, van Riet YE, Degreef E, Rutgers EJT, Wesseling J, Smidt ML. Sentinel lymph node biopsy can be omitted in DCIS patients treated with breast conserving therapy. Breast Cancer Res Treat. 2016;156(3): $517-25$.

32. Moran CJ, Kell MR, Flanagan FL, Kennedy M, Gorey TF, Kerin MJ. Role of sentinel lymph node biopsy in high-risk ductal carcinoma in situ patients. Am J Surg. 2007:194(2):172-5.

33. Huo L, Sneige N, Hunt KK, Albarracin CT, Lopez A, Resetkova E. Predictors of invasion in patients with core-needle biopsy-diagnosed ductal carcinoma in situ and recommendations for a selective approach to sentinel lymph node biopsy in ductal carcinoma in situ. Cancer. 2006;107(8):1760-8.

\section{Publisher's Note}

Springer Nature remains neutral with regard to jurisdictional claims in published maps and institutional affiliations.

Ready to submit your research? Choose BMC and benefit from:

- fast, convenient online submission

- thorough peer review by experienced researchers in your field

- rapid publication on acceptance

- support for research data, including large and complex data types

- gold Open Access which fosters wider collaboration and increased citations

- maximum visibility for your research: over $100 \mathrm{M}$ website views per year

At BMC, research is always in progress.

Learn more biomedcentral.com/submissions 